Research Article

JOURNAL OF THE CAMEROON ACADEMY OF SCIENCES Vol. 14 No. 2 (2018)

\title{
Digitization and its impact on Audio-visual Translation in Cameroon
}

\section{Ayonghe Lum Suzanne}

Associate Professor of Audiovisual Translation, Advanced School of Translators and Interpreters (ASTI), University of Buea. Email: ayonghelumsuzanne@gmail.com, s ayonghe@yahoo.com

Tel: +237677744862

\begin{abstract}
This article is aimed at assessing digitization and its impact on audiovisual translation in Cameroon. The television, information and communication technologies and new information and communication technologies are gadgets commonly used by digitization and audiovisual translation. Audiovisual translation, which depends on the television and information and communication technologies, will therefore be affected by the introduction of digitization. Any improvement on images and sound via digitization, will positively enhance subtitles and dubbed films or programmes viewed on the television. Digitization is the current trend in broadcasting, both in Cameroon and all over the world. 165 questionnaires were randomly collected from students and workers. Related documentation was also consulted. Findings revealed that: i) although there are lots of advantages associated with digitization, and that a great number of people are aware of it, its implementation level so far is still less than $50 \%$; ii) there is a positive correlation between digitization and audiovisual translation; iii) digitization is an on-going process in the country; and iv) its implementation requires important measures that must be respected by all stakeholders: policy makers, trainers and trainees, users, and the government.
\end{abstract}

Key Words: Digitization, audiovisual translation, analogue television, digital television, digital switchover.

\section{Résumé}

L'écran de télévision ou d'ordinateur, les technologies de l'information et de communication, ou encore les nouvelles technologies de l'information et de communication constituent le point commun entre la numérisation et la traduction audiovisuelle. La traduction audiovisuelle qui dépende de la télévision et des technologies de l'information et de communication, sera donc touchée par l'introduction de la numérisation. Toute amélioration des images et des sons par numérisation, va améliorer positivement le sous-titrage, les films et les programmes doublés qui sont visionnés à la télévision. La numérisation est la tendance actuelle en radiodiffusion aussi bien qu'au Cameroun que dans le monde entier. Cet article vise donc à évaluer la numérisation et son impact sur la traduction audiovisuelle dans le pays. Les données ont été collectées à travers 165 questionnaires remplis au hasard par les étudiants et travailleurs. La documentation connexe a également été consultée. Les résultats ont révélé que : i) bien qu'il existe de nombreux avantages associés à la numérisation, et qu'un grand nombre de personnes le connaissent, son niveau de mise en œuvre jusqu'à présent est encore inférieur à 50\% ; ii) il existe une corrélation positive entre la numérisation et la traduction audiovisuelle; iii) la numérisation est un processus en cours dans le pays; et iv) sa mise en œuvre exige des mesures importantes qui doivent être respectées par toutes les parties prenantes, y compris le gouvernement.

Mots clés: Numérisation, traduction audiovisuelle, télévision analogique, télévision numérique, basculement numérique.

Received: 25/09/2017

Accepted: 30/04/2018

DOI: https://dx.doi.org/10.4314/jcas.v14i2.4

(C) The Authors. This work is licensed under the Creative Commons Attribution 4.0 International Licence. 


\section{Introduction and Background}

Audiovisual translation (AVT) is a relatively new domain in Cameroon. It is still a fledgling sector both in academic and professional spheres. As of now, training in AVT in Cameroon is offered only in two translator training schools: The Advanced School of Translators and Interpreters (ASTI) in Buea and the "Institut Supérieur de Traduction d'Interprétation et de Communication (ISTIC)" in Yaounde. Consequently, AVT as a professional activity in the country has mostly been carried out by non-professionals. There has been significant interest and thus publications in the domain of AVT especially in the area of subtitling. Despite the significant number of studies carried out so far by researchers in the country (Ayonghe, 2015), one wonders why AVT still appears to be at an embryonic state.

Cameroon set 2015 for radio and television stations in the country to be digitized and its advent came abruptly and it appears Cameroonians were either taken by surprise or were not ready for it. That was probably the reason why many sectors in the Government hurriedly took the decision to digitize their information systems, even though they may probably not have been ready for the process. For instance, the Cameroon Radio and Television (CRTV), the Custom Services, the Telephone Companies (MTN, Orange, Nexttel) are currently being digitized. MTN moved first from $2 \mathrm{G}$ to $3 \mathrm{G}$ and more recently to $4 \mathrm{G}$. During a conference to pave the way for a digitized archive documentation system in Cameroon held in 2016 at the Advanced School of Mass Communication-ASMAC in Yaounde (Akana, 2016), it was evident that CRTV, Canal 2 International, STV, Equinoxe TV, Vision 4, LTM, DBS, Camnews 24, were already digitized. Furthermore, Cameroon's ancient music was also seen to be digitized (Africa Top Success, 2015).
Digital filing services for public administration documents in Cameroon will soon start (Business in Cameroon, 2017) and Banks such as Ecobank are currently digitizing their services (CRTV, 2017). There are certainly many other sectors in the country that are progressively and quietly digitizing their services or seriously thinking about digitization. The mere fact that the timing of digitization of the various sectors falls within the same time interval (2015-2016), confirms the fact that its introduction in Cameroon, came as a surprise. Furthermore, digitization was more or less imposed on some of these sectors because of the given deadline of 2015, thus the confusion in its hurried implementation.

\section{Problem Statement}

However, not all television broadcasting stations in the country have been completely digitized. Digitization is difficult, and full of lessons learned the hard way (Nicholson, 2013). Whenever digitization is introduced in a country, those companies or organisations that don't move in that direction, and move quickly, may be terribly disrupted themselves (Rick, 2017). Digitization is at its infancy in the country and so does AVT. These two technologies which have become very crucial to the political and economic growth and development in the country have to be digitized and there is no doubt that there are many advantages that come with digitization. Digitalizing Cameroon Radio Television (CRTV) coupled with Cameroon's 284 indigenous languages, automatically paves the way for AVT. This in turn, will ease broadcasting into the other languages through subtitling, dubbing and voiceover. The following research questions therefore arise: RQ1) With the advent of digitization, will Cameroon broadcasting television stations cope with its demands? RQ2) What are the advantages and disadvantages of digitization and AVT? RQ3) What impact does digitization have on AVT? RQ4) What is the way forward? 
The objectives of this article are therefore to: i) Assess the level of digitization of television broadcasting stations in the country; ii) Examine the advantages and disadvantages of digitization and AVT; iii) Find out what impact digitization has on AVT; and iv) Possibly determine the way forward.

\section{Methodology}

Data was collected from questionnaires (Table 1) and relevant documentation on digitization and AVT.

Table 1: Detail Information on the Questionnaires and the Respondents

\begin{tabular}{|c|c|c|c|c|c|}
\hline \multicolumn{6}{|c|}{ Information on the Questionnaires } \\
\hline & & & No. & $\%$ & Total (\%) \\
\hline \multirow{3}{*}{\multicolumn{2}{|c|}{ Total number of questionnaires }} & Served & 200 & 100 & 100 \\
\hline & & Answered & 165 & 82.5 & \multirow[t]{2}{*}{100} \\
\hline & & Not answered & 35 & 17.5 & \\
\hline \multicolumn{6}{|c|}{ Information on the Respondents: $165(82.5 \%)$} \\
\hline \multirow[t]{2}{*}{ Occupation } & Student & & 106 & 64.25 & \multirow[t]{2}{*}{100} \\
\hline & Worker & & 59 & 35.75 & \\
\hline \multirow[t]{3}{*}{ Educational Level } & M.A. Tran & $\mathrm{n} /$ Interpretation & 163 & 98.78 & \multirow[t]{3}{*}{100} \\
\hline & English La & ge Degree & 1 & 1.61 & \\
\hline & Bilingual D & & 1 & 1.61 & \\
\hline \multirow[t]{2}{*}{ Age Range } & 20-30 year & & 112 & 67.87 & \multirow[t]{2}{*}{100} \\
\hline & Above $30 \mathrm{~s}$ & old & 53 & 32.13 & \\
\hline \multirow[t]{3}{*}{ Gender } & Male & & 83 & 50.3 & \multirow[t]{3}{*}{100} \\
\hline & Female & & 77 & 46.66 & \\
\hline & No answer & & 5 & 3.04 & \\
\hline \multirow{3}{*}{$\begin{array}{l}\text { Languages } \\
\text { Spoken }\end{array}$} & \multirow{2}{*}{\multicolumn{2}{|c|}{$\begin{array}{l}\text { English, French, Spanish, } \\
\text { Geman, Arabic, Swahili and } \\
\text { Ngomala }\end{array}$}} & 159 & 96.36 & \multirow[t]{3}{*}{100} \\
\hline & & & & & \\
\hline & \multicolumn{2}{|l|}{ No answer } & 6 & 3.64 & \\
\hline
\end{tabular}


Both qualitative and quantitative research methods were used in this study. Data was collected from 165 questionnaires served to students and staff because they use ICTs and NICTs on daily basis. These students, who come from various regions of the country, will therefore be among the first category of persons that will be broadly affected by digitization. Excel software was used to extract, compile and analyse data from questionnaires. The findings will be presented in tables and or in percentages, backed up by concrete explanations to ease understanding.

\section{A brief history of digitization in Cameroon}

Digitization began anywhere from the late 1950s to the late 1970s with the coming and explosion of digital computers and digital record keeping that continues to the present day. According to Press (2015), digitization started from "the 1950s on, with a distinct bounce in the 1990s due to the advent of the Web, digitization has changed the way we work, shop, bank, travel, educate, govern, manage our health, and enjoy life.

In Cameroon, Cameroon Radio Television (CRTV) started broadcasting in 1985 with analogue broadcasting technology. According to the National Communication Council of Cameroon, the idea of digitization which is in its infancy, started in 2006 and was actually imposed to the country by the International Union of Telecommunications (IUT) of which Cameroon is a member. The IUT is a specialized agency of the United Nations (UN) that is responsible for issues that concern information and communication technologies (ICTs). The deadline for digitization in Cameroon was 2015. Consequently, the Government first created the National Supervision Committee for the replacement of Analogue broadcasting to Digital, known as Cam DBS (Décision n 022/SGPM of 19 April 2010) in charge of making proposals for the digitization procedures. Furthermore, the Government created in 2012 a body known as Cameroon Digital Television Service (Cam DTV), also known as the Cameroon Digital Television Project, in charge of digitization in the country and to ensure the smooth replacement of the Analogue Broadcasting Technology to Digital Broadcasting Technology (Decree No. 2012/3917 / PM OF 20 NOV 2012). This body is equally charged with the selection of the strategic partners for the purchase of the equipment.

\section{Digitization of television broadcasting stations in Cameroon}

Digitization is the conversion of text, pictures, or sound into a digital form that can be processed by a computer. According to the Business Dictionary (2017), the term digitization is defined as the conversion of analogue information in any form (text, photographs, voice or sound, etc.) to digital form with suitable electronic devices (such as a scanner or specialized computer chips) so that the information can be processed, stored, and transmitted through digital circuits, equipment, and networks. Digitization is of crucial importance to data processing, storage and transmission, because it allows information of all kinds in all formats to be carried with the same efficiency and also intermingled. This is why it is a favoured way of preserving information for many organizations around the world (JISL, 2017).

\subsection{Digital Television}

The digital television transition, also called the digital switchover, the analogue switch-off (ASO), or the analogue shutdown, is the process in which analogue television broadcasting is converted to and replaced by digital television. In many countries, a service is operated where a broadcast is made available to viewers in both analogue and digital at the same time. As digital broadcast becomes more popular, the existing 
analogue services will be removed progressively. In Cameroon, a deadline of June 2015 was given by the Government all over the national territory (NGON, 2015). The switchover for individual countries varies; in some countries, it is being implemented in stages as in Australia, India and the United Kingdom. In others, the whole country switches off on one date. Cameroon switched off on Tuesday 14 July 2015 as required by IUT.

\subsection{Audiovisual Translation}

AVT, also known as "screen translation", "film translation" or "Multimedia translation", is a term used to refer to any language and cultural transfer aimed at translating original dialogues coming from any acoustic or visual product. It is the translation of recorded audiovisual material. The term audiovisual is used to bring to the forefront the multisemiotic dimension of all broadcast programmes (Gambier, 2003).

\subsection{The link between Digitization and AVT}

AVT became more familiar and more frequently discussed in translation studies since the introduction and success of the New Information and Communication Technology (NICT). This implies a correlation between Digitization and AVT. The growth and development of one of these two can therefore impact the growth and development of the other and vice versa. Digitization has to do with, amongst others, Radio Broadcasting, Television Broadcasting, Computers and Information and Communication Technology (ICT) or NICT. Therefore, the first link between these two is the Television or Computer screen. The second is that both use ICTs and/or NICTs. The third link is that they both need each other to comfortably expand very rapidly, political and economic growth and development in the country, as well as teaching and learning, through AVT, of English, French and the 284 local languages that exist in the country. This shows that technological innovation has impacted the field of AVT which on its part, also needs a digital transformation in order to ease its uses and the use of its services by those interested in the field. Therefore, there are lots of advantages that are linked to digitization.

\section{Findings}

\subsection{Findings from questionnaires}

The results from the questionnaires are presented in table 2.

The four major points derived from Table 2 are highlighted as follows:

i. Even though a great number of respondents have access to TVs $(82.14 \%)$, and have heard of digitization before $(78.57 \%)$, up to $50 \%$ still believe their TVs are not digitized and $4 \%$ don't even know whether their TVs are digitized or not; ii. A great number of respondents (89.29\%) have heard of AVT before, $75 \%$ think digitization and AVT are linked; and $89.43 \%$ say they are linked through TV, ICTs or NICTs.

iii. Only $57 \%$ of the respondents have heard of analogue TV before as compare with $78.57 \%$ who have heard of digitization before.

iv. In terms of preference, none of the respondents preferred analogue TV (0\%); while $85.71 \%$ preferred digital TV and the rest $(14.55 \%)$ said nothing.

\subsection{Findings from documentation}

\subsubsection{Advantages of digitization of television broadcasting}

The transition from analogue to Digital Terrestrial Television (DTT) can be considered a natural evolution for the broadcasting industry. While the adoption of digital broadcasting has been led by 
Table 2: Results from questionnaires

\begin{tabular}{|c|c|c|c|}
\hline Question & Answer & $\%$ & Total $(\%)$ \\
\hline \multirow[t]{2}{*}{ Do you have a TV? } & Yes & 82.14 & \multirow[t]{2}{*}{100} \\
\hline & No & 17.86 & \\
\hline \multirow{3}{*}{$\begin{array}{l}\text { Have you ever heard of digitization of TV in } \\
\text { Cameroon? }\end{array}$} & Yes & 78.57 & \multirow[t]{3}{*}{100} \\
\hline & No & 14.29 & \\
\hline & No answer & 7.27 & \\
\hline \multirow[t]{3}{*}{ Are images viewed on your TV digitized? } & Yes & 46 & \multirow[t]{3}{*}{100} \\
\hline & No & 50 & \\
\hline & Don't know & 4 & \\
\hline \multirow[t]{3}{*}{ Have you ever heard of AVT? } & Yes & 89.29 & \multirow[t]{3}{*}{100} \\
\hline & No & 3.57 & \\
\hline & No answer & 7.14 & \\
\hline \multirow[t]{2}{*}{ Is there a link between digitization and AVT? } & Yes & 75 & \multirow[t]{2}{*}{100} \\
\hline & No & 25 & \\
\hline \multirow[t]{3}{*}{ What, in your own opinion, links digitization to AVT? } & TV screen & 52.53 & \multirow[t]{3}{*}{100} \\
\hline & $\begin{array}{l}\text { ICTs and/or } \\
\text { NICTs }\end{array}$ & 36.90 & \\
\hline & No answer & 10.57 & \\
\hline \multirow[t]{3}{*}{ Have you ever heard of analogue TV? } & Yes & 57 & \multirow[t]{3}{*}{100} \\
\hline & No & 21.20 & \\
\hline & No answer & 21.80 & \\
\hline \multirow{3}{*}{$\begin{array}{l}\text { Between analogue TV and digital TV, which one do } \\
\text { you prefer? }\end{array}$} & Analogue TV & 00 & \multirow[t]{3}{*}{100} \\
\hline & Digital TV & 85.71 & \\
\hline & No answer & 14.55 & \\
\hline
\end{tabular}


cable and satellite, the transition of the terrestrial broadcast platform will arguably bring most benefits to society. This is especially true for countries where the size of the terrestrial platform is large and terrestrial TV is the primary mode of TV reception for most households (e.g. Cameroon). Generally, digital broadcasting has enormous benefits it can render to both the audience and broadcasters. These benefits could be in the direction of programme content, media convergence, quality signals and multiple channels. Different sectors of the society shall benefit in different ways (Ihechu \& Uche, 2012). The benefits of DT'T include:

\subsubsection{National Benefits}

One of the main advantages is that there will be better bandwidth usage. Thus, the spectrum can be applied to other services. Furthermore, the image quality delivered by digital signals is more efficient when it comes to image quality.

\section{Benefits for the broadcasters}

i) The broadcasters are going to enjoy an era of cost effectiveness with digital broadcasting since a station can carry up to four channels on the same frequency.

ii) There are equal opportunities that will result in healthy competition.

iii) Spectrum efficiency gains (better bandwidth) and increased transmission capacity

iv) DTT typically allows between 4 and 18 services to be accommodated.

v) Improved signal quality and robustness

vi) Lower energy consumption and maintenance costs

vii) Flexibility and more efficient use of infrastructure

viii) Stimulates demand in the consumer electronic market

\section{Benefits for the Consumers}

i) Digital broadcasting will afford the viewers more programming choice arising from efficient spectrum utilization.

ii) It plays a vital role in information dissemination due to its high receptivity, vast coverage and efficiency.

iii) The viewers are going to receive clearer pictures.

iv) Wider choice of programming and services (including additional channels, HD offerings, radio, data services, pay programmes)

v) Better quality: less likely to experience signal interference and picture quality issues.

vi) Automatic tuning.

vii) It offers a range of interactive applications (games, enhanced teletext, multi-lingual subtitling, audio-description),

viii) It allows viewers to watch programmes at a time of their choosing, multiple reception outlets, capability to record programs

ix) It gives room for parental lock setting and control of programmes broadcasted.

\section{Benefits for Content Providers}

i) The content providers have increased avenue for legitimate exploitation of works, for airing programmes, and for all genres of programmes (Udeorah; 2009).

ii) As the existing broadcast stations start increasing the number of channels resulting from the digitization process, the demand for programmes will increase. This will create competition which will result to quality content provision thereby maximizing profit.

\section{Benefits for the Regulator Body}

Cam DTV, will be acquiring increased revenue that will be accruing from additional licences. On the long run, specialized areas of broadcasting will be encouraged, thereby addressing areas that were previously neglected by commercial broadcasters. 


\section{Other Benefits}

Other benefits include:

i) Narrowing digital divide and reaching unserved areas (rural remote areas in Cameroon) ii) E-government and other public services are facilitated

iii) Resilience of communications infrastructure is ensured: DTT, by providing an alternative communications platform, improves the resilience of a country's communications infrastructure. This is particularly important in times of national crises, e.g. natural disasters or cyber-attacks.

iv) Create a good avenue for advertisers.

\subsubsection{Disadvantages of digitization of television broadcasting}

Despite the benefits associated with digital broadcasting, there are several factors that pose challenges to the process. These include:

i) The replacement of analogue sets with flatpanel screens or get decoders by Cameroonian households.

ii) The ban of importation of analogue television sets in Cameroon. As such, households are advised to acquire digital radio sets and flatpanel TV screens which will enable them enjoy digital broadcasting

iii) The deadline to migrate to digital television was set to be 2015 .

iv) Huge financial means are required for the purchase of switchover from analogue to digital broadcasting equipment and gadgets.

v) The trainers and the training of trainees are required. The task of training and retraining personnel to fit into the digital process poses a problem. Furthermore, the number of stations will increase.

vi) The power sector in Cameroon, Energy of Cameroon (ENEO) also poses some problems here because of frequent power cuts. Something has to be done about it. vii) Awareness: People like the audience, government officials and sundry, need to be educated on the digitization process.

\subsubsection{Advantages of AVT}

AVT encompasses Subtitling, Dubbing and VoiceOver. The advantages of AVT are numerous. AVT is used:

i) In the classroom for teaching and learning; in the promotion and the implementation of bilingualism and multilingualism (Ayonghe, 2009);

ii) In the implementation of language policies and the promotion of Cameroonian national languages;

iii) To translate all forms - radio, television, internet - of audiovisual material.

iv) With dubbing, viewers don't stress up when watching TV programmes or films since they will rarely be able to identify potential mistakes.

v) Voice-over is popularly being used commercially, in television advertising since the beginning of radio broadcasting.

In Cameroon, research has shown that AVT, though still in its infancy, can be used to teach and learn programmes and languages both official and indigenous languages and thus bilingualism/ multilingualism as well as in the implementation on language policies. Voice-over is currently being used in CRTV for interviews and adverts (Ayonghe \& Enow, 2013).

\subsubsection{Disadvantages of AVT}

i) With subtitling, the main difficulty resides in making the transition from the oral to the written code on the screen. The audience's attention is sometimes divided between following the trend of the film and reading the translated words on the screen. Subtitles are mainly criticised because they omit elements of the original dialogue.

ii) Dubbing's most striking disadvantage is probably the loss of authenticity: the original voices are replaced, extra textual elements make 
it often impossible to maintain the illusion of authenticity, and lip synchronisation is often very difficult to attain.

iii) Dubbing a movie can be up to 15 times more expensive than adding subtitles. Consequently, dubbing is more expensive and more time consuming than subtitling.

It can be deduced from above that the disadvantages of AVT are mostly technically related.

\section{The Impact of Digitization on AVT}

Firstly, since digitization implies moving from the old to new and modern equipment, the replacement of analogue equipment with digital equipment, better TV screens, good quality images, more facilities for viewing subtitles, modern computers, etc., shows that AVT which also uses TV screens and ICTs or NICTs, will automatically improve because of improved equipment. Secondly, since Cameroon has two official languages (English and French) and about 284 local languages (Ethnologue, 2017) which automatically makes it a fertile ground for translation in general and AVT in particular, any improvement brought about by digitization, will also bring improvement on AVT, technologically, economically and even politically. Therefore, the impact of digitization on AVT, especially in Cameroon is going to be great if well implemented.

\subsection{Technologically and Economically}

The fact that Cameroon is a bilingual country with English and French as official languages, alongside 284 national languages, opens the way for translation as a whole and AVT in particular. Based on the country's bilingualism/ multilingualism policy and the determination of its leaders to promote both official and national languages, the practice of translation is highly encouraged (Ako, 2013). Given the multilingual and multicultural nature of Cameroon, digitization through AVT will rapidly promote bilingualism and multilingualism, language acquisition, literacy training and academic literacy.

The Internet is entirely dependent on telecommunications networks for data transmission. The type and quality of those networks determine the level of connectivity. In general, the quality of the underlying telecommunications infrastructure and bandwidth (i.e., transmission and carrying capacity) for international connections are the measures of quality. Other more direct measures of connectivity are the number of telephone lines per capita in a given country and the cost of computer hardware equipment and software. Digitization of equipment will positively change this sector.

Digitization means improved signal quality and robustness, lower energy consumption and maintenance costs, equal opportunities with healthy competition, bandwidth efficiency gains and increased transmission capacity, as well as flexibility and more efficient use of infrastructure. With the introduction on digitization, "we could dream of digitopia" (Gambier, 2006). This will positively influence the use and cost of using audiovisual products and AVT thereby encouraging the Government to adopt an AVT policy in in the country. More schools will be encouraged to use AVT in classrooms with lower costs. CRTV will be encouraged to use and practise AVT in their audiovisual Unit. Digitization will bring about the following for everybody including the translators in the country: The length of time between films being made and when they are shown (in DVD, on the Internet and the mobile phone) will be short.

The commercial and technical convergence between the media, telecommunication and ICT will speed up, and the relationship between the 
copyright holders and broadcasters will also change rapidly. New services such as streaming, video and TV on demand, TV on mobile (with new types of very short films), podcasting, etc., will challenge not only providers but also screen translators. The way audio-video-radio programs are accessed and consumed will change the whole management and financing of the audiovisual sector. The type and size of the programs will motivate and strongly encourage the production, use and consumption of subtitling, dubbing, interpreting and voice-over and related products.

Nowadays, NICTs are considered both as the most updated and modern technologies used in the management of eEconomy as well as to perform any audiovisual task. NICTs dynamically facilitated the transition from traditional dubbing to digital dubbing. This study shows that digitization will equally facilitate and encourage the development, production, use, consumption and purchase of AVT and related products (Teumagou \& Ayonghe, 2016) in Cameroon.

Right now, in the country, virtually all sectors are going through digitization: the radio and television sectors, the universities, the music sector, the customs sector, the heath services, the ministries, the banks, even the transport sectors and many other sectors not yet identified. Everybody wants to go digital. Everybody talks digital. Most Cameroonians are so excited about digitization.

The drawback here is that even though most companies are excited about digitization and would really like to engage in the process, there is no guarantee that once they start the process, they will get to its completion. The Government supervisory body may not follow up to ensure that. Some companies will be created, and some will close. There must be some follow up, some advice, some assistance for these companies to digitize in the right direction.

\subsection{Political Consideration}

There is a popular saying that, where there is a will, there is a way. The Government accepted and embraced digitization. If the Government wants it to work fully, it will work fully. It will now depend on its priorities. Digitization is not only a technological and economical issue. It is very strongly political. The Government must therefore ensure that digitization, once introduced, must work maybe progressively and its rules must be respected by all, no matter what happens and no matter who is concerned.

\section{Conclusion, discussion and the way forward}

Going back to Table 2, it is clear that even though $78.57 \%$ of the respondents had heard about digitization before, up to $54 \%$ don't still understand what it is all about. Furthermore, only $46 \%$ of the respondents had digitized TVs. This is an indicator of the level of digitization in the country. Interestingly, $89.29 \%$ of the respondents have heard about AVT before; $75 \%$ of them strongly believe that there is a link between AVT and digitization; and $89.43 \%$ indicated that the connexion between digitization and AVT is TV screens, ITCs and/or NICTs. Thus, digitization of the TV automatically improves AVT and related modes. Going back to the research questions at the beginning of this study, 1) it is clear from this study that for the country to digitize completely and for Cameroon broadcasting television stations to cope with its demands, concrete follow-up measures must be implemented by all concerned: policy makers, trainers and trainees, users, and the government itself. 2) There are advantages and disadvantages of digitization and AVT. However, the advantages far outweigh the disadvantages as shown in this study. 3) Technologically and economically, digitization has an impact on AVT (Teumagou \& Ayonghe, 2016; Gambier, 2006). Politically, digitization will work if that is the will of the 
Government. 4) The way forward is for the government to put in place concrete follow-up mechanisms to ensure that digitization should be completed by 2018 as agreed.

The following key lessons learned from this study are highlighted as follows:

i) Digital switchover only works if Government led (there has to be clear legislation, regulation and an overall coordination body in place).

ii) A functioning supply chain is crucial for a smooth process (without this it is not possible to ensure that consumers have access to new receiver equipment at the right time).

iii) Digital broadcasting enables more services to be offered but this is only of benefit if the content is there (the right content to attract viewers and enough of it) to use the capacity/ capability DTT offers. In the UK, this was especially true for commercial broadcasters who need advertising revenue on their platforms. CRTV could use voice-over for this same purpose. iv) Adequate funding across the supply chain is very important to ensure success; in the $\mathrm{UK}$, for instance, having a large market size helped and $\mathrm{BBC}$ licence fees were the main source of funding; in smaller countries and lower income countries like Cameroon, large government subsidies may be required.

Nigeria, Ghana, and the UK (Revolvy, 2017), have digitized services in their countries and the process is still going on especially in Nigeria. Cameroon can also learn and gain from their experience. The ITU set 2015 for the entire broadcasting stations in the world to go digital. Nigeria set 2012 for broadcast stations in the country to be digitized (Ihechu \& Uche, 2012). Cameroon set 2015 for digitization. All the requirements related to this new technology imposed on Cameroonians were also imposed on Nigerians but the fact that theirs started before ours, shows that we have to learn from their experience. A careful look at the unfolding events suggests that both broadcasters and consumers do not have the basic information required to complete the project.

It should be recalled that, in line with the transition process, the ITU set June 17, 2015 for all UHF channels to have gone digital. It also set the digitization of all VHF channels for 2020 (Aihe, 2008). Therefore, Cameroon should try hard to follow the world schedule for digitization like other African countries such as Nigeria and Ghana.

\section{References}

Africa Top Success (2015). 85 million FCFA for the digitization of ancient music. [Web:] https:// www.cameroonweb.com/CameroonHomePage/ entertainment/85-million-FCFA-for-thedigitization-of-ancient-music-318252. Date of access: 04 September 2017.

Aihe, O. (2008). HDTV: Nigeria begins digital broadcast journey. Vanguard. In: Ihechu, I. P. \& Uche, U. (2012). The Challenges of Digitization of Broadcasting in Nigeria. New Media and Mass Communication, Vol 5. [Web:] www.iiste.org. Date of access: 04 September 2017.

Akana, R. (2016). Cameroon holds conference for a digitized archive documentation system. [Web:] http://www.cameroonintelligencereport.com/ cameroon-holds-conference-for-a-digitizedarchive-documentation-system/. Date of access: 04 September 2017.

Ako, M. S. (2013). Assessing Media Accessibility for the Hearing Impaired through Subtitling. M.A. Thesis. Unpublished. University of Buea.

Ayonghe, L.S. 2009. Subtitling as a Tool for the Promotion of Bilingualism/Multilingualism in Cameroon. In: Tanda V., Jick H. K., and Tamanji P. N. (eds.) Language, Literature and Social 
Discourse in Africa. Departments of English and Linguistics, University of Buea. Pp 106-120.

Ayonghe, S. L. (2015). An assessment of the Audiovisual Landscape in Cameroon. [Web:] http://www.translationjournal.net/January2015/an-assessment-of-the-audiovisualtranslation-landscape-in-cameroon.html. Date of access: 18 September 2017.

Ayonghe, S. L. \& Enow, F.E. (2013). Audiovisual Translation in Cameroon: An Analysis of Voiceover in Cameroon Radio and Television (CRTV). Journal of the Cameroon Academy of Sciences. Vol. 11 No. 2 \& 3 pp 173-181.

Business Dictionary. (2017). [Web:] www.businessdictionary.com/definition/ digitization.html. Date of access: 01 September 2017.

Business in Cameroon. (2017). [Web:] https:// www.google.cm $/$ search?q=Business + in +

Cameroon,+2017 \&newwindow $=1 \&$ client $=$ firefox$\underline{b} \& \mathrm{dcr}=0 \& \mathrm{tbm}=$ isch\&tbo $=\mathrm{u} \&$ source $=$ univ\&sa =X\&ved=0ahUKEwiSmYeJgY7WAhWFCBoKHX wICKkQ7AkIbw\&biw=1366\&bih=659. Date of access: 01 September 2017.

Ethnologue (2017). Languages of the World, Twentieth edition. Dallas, Texas: SIL International. Online version: http:// www.ethnologue.com. Date of Access: 01 September 2017.

Gambier, Y. (2006). Multimodality and Audiovisual Translation. [Web:] http:// euroconferences.info/proceedings/ 2006 Proceedings/2006_Gambier_Yves.pdf. Date of access: 06 September 2017.

Gambier, Y. (2003). "Screen Transadaptation: Perception and Reception", University of Turku, Finland, in The Translator, Vol 9, No. 2, pg 171189.

Ihechu, I. P. \& Uche, U. (2012). The Challenges of Digitization of Broadcasting in Nigeria. New
Media and Mass Communication, Vol 5. [Web:] www.iiste.org. Date of access: 04 September 2017.

Jindal Infra Solutions Limited (JISL). (2017). [Web:] http://www.jindalinfra.in/ digitalization.php. Date of access: 01 September 2017.

NGON, O. (2015). Cameroun - Audiovisuel: Le Cameroun bascule finalement à la TNT après un retard d'un mois. [Web:] http://www.camerooninfo.net/. Date of access: 01 September 2017.

Nicholson, B. (2013). THE DIGITAL TURN: Exploring the methodological possibilities of digital newspaper archives. [Web:] http:// www.tandfonline.com/doi/abs/10.1300/ J123v49n01 06?journalCode $=$ wser20. Date of access: 01 September 2017.

Press, G. (2015). A Very Short History of Digitization. [Web:] https://www.forbes.com/ sites/gilpress/2015/12/27/a-very-short-historyof-digitization/\#3c16521249ac. Date of access: 01 September 2017.

Revolvy (2017). Digital switchover dates in the United Kingdom. [Web:] https:// update.revolvy.com/topic/Digital $\% 20$ switchover $\% 20$ dates $\% 20 \mathrm{in} \% 20$ the $\% 20$ United $\% 20$ Kingdom \&item type $=$ topic

Rick, T. (2016). The real challenges of digitization is not technology. [Web:] https:// www.torbenrick.eu/blog/technology/the-realchallenges-of-digitization-is-not-technology/. Date of access: 01 September 2017.

Teumagou, N. C. \& Ayonghe, L. S. (2016). L'Apport des Nouvelles Technologies de l'Information et de la Communication dans le Doublage Numérique. Journal of the Cameroon Academy of Sciences, Vol 13, No 1-2, pp 63-74.

Udeorah, B. (2008). Setting the roadmap to digitization. In: Ihechu, I. P. \& Uche, U. (2012). The Challenges of Digitization of Broadcasting in Nigeria. New Media and Mass Communication, Vol 5. [W 